\title{
Analisis Industri Kakao di Indonesia
}

\author{
Fidela Izza Nashita \\ Program Studi Kewirausahaan \\ Universitas Bina Nusantara \\ fidela.nashita@binus.ac.id
}

Industri adalah sekelompok perusahaan yang memproduksi produk atau layanan serupa, seperti kendaraan, smartphone, dan barang lainnya. Industri sangat bervariasi seperti, tingkat pertumbuhan, struktur, karakteristik keuangan, dan daya tarik keseluruhan. Tren yang mempengaruhi industri juga penting.

Technopreneurship merupakan gabungan dari kata technology dan entrepreneurship. Technopreneurship yaitu memanfaatkan teknologi yang berkembang untuk dijadikan peluang usaha atau metode untuk mengolah sesuatu agar terjadi efisiensi biaya maupun waktu, sehingga dapat menghasilkan produk yang lebih berkualitas.

Kakao merupakan salah satu komoditas perkebunan di Indonesia yang mampu meningkatkan devisa negara. Namun mutu kakao Indonesia khususnya produksi biji kakao perkebunan rakyat masih rendah. Jika petani perkebunan kakao rakyat mengolah biji kakao dengan teknologi fermentasi maka akan didapatkan mutu dan nilai ekonomi yang lebih baik karena harga biji kakao fermentasi lebih tinggi daripada harga biji kakao yang tidak difermentasi. Sehingga harus adanya bimbingan teknis pengelolaan biji kakao dari pemerintah daerah kepada petani perkebunan rakyat kakao agar mutu biji kakao petani dapat ditingkatkan.

Usaha pemerintah dengan Gerakan Peningkatan Produksi dan Mutu Kakao Nasional (GERNAS) adalah untuk meningkatkan daya saing kakao Indonesia ke dunia internasional. Agar kakao rakyat lebih mandiri maka pemberdayaan harus diarahkan ke agroindustri. Untuk memberdayakan kakao rakyat menjadi masyarakat mandiri berbasis agroindustri kakao, harus didukung oleh komoditas kakao nya sendiri mulai dari on-farm sampai off-farm yang saling terkait satu sama lain dan bersifat terpadu dan berkelanjutan.

Peluang dari industri kakao ini cukup besar sehingga dengan adanya Technopreneurship yang diterapkan mampu meningkatkan pendapatan dan kemakmuran petani kakao. Target pasar perusahaan adalah bagian terbatas dari industri yang dituju atau dicoba untuk menarik pada titik waktu tertentu. Kebanyakan perusahaan tidak mencoba untuk melayani seluruh industri mereka. Sebaliknya, mereka fokus melayani porsi pasar yang terspesialisasi dengan baik. 
Technopreneurship merupakan bisnis berbasis teknologi. Technoprenurship di dalam industri nyata berfungsi untuk menghubungkan kebutuhan industri kecil terhadap teknologi dalam membantu meningkatkan produktivitas usahanya. Media yang digunakan adalah teknologi website e-commerce. Situs e-commerce bertujuan untuk menghasilkan situs yang mampu memperkenalkan industri kecil secara online, mampu menjangkau ke seluruh dunia, dan mampu beroperasi selama 24 jam nonstop. Hal ini dapat dimanfaatkan untuk memperluas pangsa pasar kakao ke seluruh dunia. Selain meningkatkan pendapatan petani, hal ini juga dapat meningkatan pendapatan devisa negara.

\section{References}

Barringer, B. R. (2015). Preparing Effective Business Plans: An Entrepreneurial Approach (2nd ed.). Pearson Education Limited.

Manalu, R. (2019). Pengelolaan Mutu Biji Kakao Petani Perkebunan Rakyat melalui Teknologi Fermentasi untuk Memperoleh Nilai Ekonomi yang Lebih Baik. Jurnal Ekonomi dan Kebijakan Publik, 9(2), 99-112. https://doi.org/10.22212/jekp.v9i2.1006

Muhsin, A. (2014). Muhsin, A. (2014). Aplikasi Technopreneurship untuk Mengembangkan Industri Kecil Melalui Penggunaan Teknologi E-Commerce Berbasis Content Management System: Studi Kasus pada UKM Mandiri Gypsum. Telematika, 10(2). https://doi.org/10.31315/telematika.v10i2.276

Siregar, D., Purnomo, A., Mastuti, R., Napitupulu, D., Sadalia, I., Sutiksno, D. U., Putra, S. H., Sahir, S. H., Revida, E., \& Simarmata, J. (2020). Technopreneurship: Strategi dan Inovasi. Yayasan Kita Menulis. https://kitamenulis.id/2020/04/13/technopreneurship-strategi-dan-inovasi/

Trimo, L., Hidayat, S., \& Sulistiyowati, L. (2020). Mimbar Agribisnis: Jurnal Pemikiran Masyarakat IImiah Berwawasan Agribisnis. 